\title{
Power and Integration. An Historical Overview on Euro- Mediterranean Relations
}

\author{
Kuvvet ve Entegrasyon: Avro-Akdeniz İlişkilerine Tarihsel Bir Bakış
}

\author{
Massimiliano TRENTIN*
}

\begin{abstract}
This contribution aims to analyze the power relations underlying the international relations of the Mediterranean space since the late XIX century in order to assess if and how the most recent initiatives implemented by the European Union (EU) represent continuity or discontinuity with the modern past. The main idea is that the European Union has tried to shape the Mediterranean space along its basic preference for free access to the markets of the southern and eastern countries of the Mediterranean, similar to what European powers did in late XIX and early XX century: the liberal order of the "Levantine" period combined the patterns of cooperation and consent, which were needed to foster market and elite integration, with those of conflict and coercion, which in turn were required to enforce the Europeanled economic and political order against restive and opposition forces. Compared to the past, however, the European Union has succeeded only partially in enforcing a "neo-liberal order" because it lacks meaningful political and military capacity for coercion against partners and rivals. The current crisis of liberal forces across Europe and the Mediterranean has enhanced those forces advocating a return to "state sovereignty" and control over flows of people, goods and ideas. This might recall the early postcolonial period of the 1950s and mid-1970s where the states struggled either to retain power and wealth, or overcome related asymmetries, by standing firm and "tough" in negotiations and resisting foreign interventions. However, if the centralized state was the main political and institutional driver of that period, it is highly difficult that today current states might effectively claim a monopoly over the economy and the public space on highly differentiated, secularized and interconnected societies like the Mediterranean ones.
\end{abstract}

Keywords: Integration, European Union, Euro-Mediterranean, Space, Power

Öz

Bu makale, Avrupa Birliğinin son zamanlardaki girişimlerinin geçmişle bugün arasında bir süreklilik mi yoksa kopuş manasına mı geldiğini anlamak için Akdeniz alanının arka planında işleyen güç ilişkilerinin uluslararası ilişkilerini analiz etmeyi amaçlar.

Temel fikir, Avrupa Birliğinin Akdeniz alanını Güney ve Doğu Ülkelerinin pazarlarına serbestçe erişebilmek amacıyla, tıpkı 19. ve 20. Yüzyılda Avrupalı güçlerin yaptıkları gibi şekillendirmeyi

* Massimiliano Trentin, Assistant Professor of History and Institutions of Western Asia, Department of Political and Social Sciences, Alma Mater Studiorum, University of Bologna, massimiliano.trentin@unibo.it. 
amaçladığıdır. Levanten döneminde, piyasa elit entegrasyonunu güçlendirmek için ihtiyaç duyulan işbirliği ve rıza unsurları, Avrupa liderliğindeki ekonomik ve siyasi düzeni muhalif ve direnen güçlere kabul ettirmekiçin kullanılan, zorlayıcıve çatışmacıögelerle, birleştirilmişti. Geçmişlekarşılaştırıldığında Avrupa Birliği, diğerlerini, neo-liberal düzene uyuma zorlama konusunda, sadece kısmi bir başarı elde etmiştir. Tam başarılı olamamasının nedeni Avrupa Birliğinnin ortaklarını ve rakiplerini zorlayacak anlamlı bir siyasi ve askeri kapasitesinin olmamasıdır. Avrupa'daki ve Akdeniz'deki liberal güçlerin karşı karşıya olduğu kriz "devlet egemenliğine" ve insanların, malların ve fikirlerin akışı üzerinde kontrol tesis edildiği döneme geri dönülmesi gerektiğini savunan güçleri büyütmüştür. Bu durum 1950lerdeki ve1970lerin ortalarındaki koloni sonrası dönemi çağrıştırır. Bu dönemde devletler ellerindeki gücü ve zenginliği korumak veya bununla ilgili asimetrilerin üstesinden gelebilmek için müzakerelerde sıkı ve sert pozisyon almışlar ve dış müdahalelere karşı direnmişlerdir. Unutulmamalıdır ki, merkeziyetçi devlet o dönemin temel siyasi ve kurumsal itici gücüdür. Günümüzde ise, Akdeniz'deki gibi birbirine bağlanmış, laikleşmiş ve farklılaşmış toplumlara sahip devletlerin ekonomi ve kamusal alan üzerinde tekel olma iddiasını sürdürebilmeleri oldukça zordur.

Anahtar Kelimeler: Entegrasyon, Avrupa Birliği, Avro-Akdeniz, Bölge, Kuvvet

\section{Introduction: The European-Led Levantine Mediterranean}

The Mediterranean space might be described as one of the "densest" spaces in world history because of the intensity of the flows of people, goods and ideas among the different social units that came into contact through its seas and shores (Braudel, 1985, p. 8) ${ }^{1}$. Here, conflict and cooperation, as patterns of interaction characterized the relations between those political units which acted upon the Mediterranean space during the last two centuries: namely, the European states, which evolved into a unique combination of nation and imperial states, and the Ottoman Empire, whose successors are the current Turkish and Arab states. The Kingdom of Morocco enjoyed the peculiarity of full independence from the Ottomans but followed a similar path as far as relations with European states are concerned since the late XIX and early XX century. Though it might be challenging in theory, the historical praxis has shown that both conflict and cooperation could reflect the international relations of the Mediterranean space at the very same time, for the very same actors. Ultimately, so far conflict and cooperation have proved not to be mutually exclusive patterns of interaction: better, cooperation has taken place as the result of either an asymmetry of power which institutionalized European dominance and leadership or a balance of power which let Turkish and Arab leaders assert their own priorities towards the northern partners. In all cases, cooperation has mostly been unavoidable for all parties concerned. The question was thus about the conditions for relationship and partnership.

Along with the territories of the Balkans, the Mediterranean sea has been the space where European powers interacted most with the authorities and subjects of the Ottoman Empire. For the most important imperial states of Europe in the XIX century, namely Great Britain, France

1 The literature on the history and features of the Mediterranean space is immense and cannot be reviewed here. For this reason, I would refer only to those works focused on specific features of the international relations in the Mediterranean. 
and the Tsarist Empire as well, the Mediterranean basin was a space to assert their legitimacy as continental and world powers. So called "latecomers" like Germany and Italy followed similar rationales as they approached Ottoman and local authorities in the Mediterranean basin (Carperntier, Lebrun, 2001, p. 213, 307). The "sea-in-between" still provided the fastest route for the colonial jewels of the British Empire, that is India and South East Asia, or the contested wealth of Chinese lands and society. Indeed, the control of the "enlarged" Mediterranean space, from Gibraltar to Suez and Aden was functional to the exercise of power on a global scale for Europe (Di Nolfo, 2012, p. 9). The imperialist expansion of European powers increased the eastwest, horizontal dimension of the Mediterranean space as the worthy passage to South and East Asia (Arrighi, Ahmad, Shih, 1999, p. 220). The value of stability of trade routes increased along with the industrial revolution in Europe which, coupled with imperialism, re-balanced the wealth exchange with Asia and enforced industrial manufacturing products into the latter's consumption patterns. Within the framework of the so-called "European Concert" of powers, Great Britain could foster the point of leaving the Ottoman Empire in place as long as it remained subaltern to European powers in terms of economic penetration and strategic interests. Hence, European rivalry against the Sublime Door could continue on the "margins", as in Algeria from 1830 or in the Balkans as long as it did not involve the generalized collapse of the Ottomans.

The generalization to all European countries of the clauses of the Balta Liman Agreement, negotiated by the British with the Ottomans in 1838 in exchange for military security against their ambitious Egyptian province, appeased imperialist rivalry and contributed significantly to the movement of the Ottoman economy and society towards a kind of "periphery" within the new international division of labour (Puryear 1969, p. 83; Pamuk, Williamson, 2009, p. 5). Since the second half of the XIX century, the balance of payments between European and Ottoman empires proved negative for the Sublime Door and its provinces, whose production faced the massive inflows of European goods not compensated by proportional exports or financial investments. Moreover, though some local manufacturing could resist European competition as for domestic consumption, the exports of the Levant and Egypt turned increasingly towards raw materials (cotton, flour), whose value proved to be anyway lower than the intermediate and consumption goods imported from Europe (Owen, 1981; Pamuk, Williamson, 2009). Slowly but steadily, the bulk of the economy of the South and East Mediterranean shifted to raw materials export, transit trade and consumption, with the related social and political rise of large landowners and trade intermediaries, who often came to be the same persons or belong to the same influential families and communities. Urban centres on the coasts of the Mediterranean sea, like Algiers, Oran, Tunis, Tripoli, Alexandria, Haifa, Beirut and Izmir flourished as long as they became "hubs" for transit and retail trade, and terminals for the transport of goods from the rural inland to the sea and eventually Europe. Inland urban centres could retain their status as consumption spaces and as long as they maintained control over peasantry in the productive plains and contained the restive nomads of the deserts (Laurens, 2010; Quataert, 1994, p. 764). The deficit against Europeans was to be paid by increasing taxation at home and by external borrowing which both slowly undermined the financial and political legitimacy of the Ottoman central authorities. The 
bankruptcy of the Ottoman Empire in 1878 and the Egyptian province in 1880 transferred de facto the ultimate control of finances into British and French hands, whose primary goal was keeping these territories to serve their debt. This meant harsh "austerity" over communities, and the peasantry in particular, but not to the point of "killing" the indebted partner, which was still worth enforcing for wealth transfer as well as to prevent the disruption of trade routes (Thobie, 1985, p. 72).

The so-called Levant, originally describing the eastern territories of the Mediterranean, and Egypt became an integrated space but subaltern to European economies and powers (Pamuk, 1987, p. 55, 82; Laurens, 2010, p. 33). However, the southern and eastern shores of the Mediterranean were subaltern to Europe for two reasons. On the one hand, most of the wealth generated in this space was transferred to Great Britain, France, Germany or Russia by way of a division of labour where the ultimate recipients of profits were located in Europe, though local intermediaries could retain a significant share (Wallterstein, Decdeli, Kasaba, 1987, p. 96). On the other hand, European governments could enforce their interests, economic or political, by way of direct control over state institutions like France in Algeria (1830), its protéctorats in Tunisia (1881) and Morocco (1912), Great Britain's protectorate in Egypt since 1882, Italian colonialism in Tripolitania and Cyrenaica since 1911, the sectarian condominium in Mount Lebanon or the enforcement of debt servicing on Ottoman central finances since 1878 (Thobie, 1985, p. 128; Laurens, 2007). This was the time when Ottoman society experienced a double divergence in social conditions, namely in public health and income: on the one hand, health, education and income were concentrated in a tiny group of communities, mostly linked to European networks, whereas the peasantry and public officials experienced a decline in wealth and social status; on the other hand, Ottoman societies began lagging far behind the social conditions that Europe began to improve since the mid-XIX century (Quataert, 2005, p. 115-118).

The increasing rivalry between European powers in the Mediterranean space during the early XX century reached an apex with the First World War when Great Britain, France and Tsarist Russia rallied against the alliance between the Ottomans, the German Reich and Austro-Hungarian Empire. The final demise of the Ottoman Empire led to the formal fragmentation of the south and east Mediterranean territories into different legal and political spaces. As a matter of fact, the Great War accelerated the process of subaltern integration of the Arab and Ottoman Mediterranean space into imperial Europe but also provided a first, major opportunity for local, autonomous forces (Corm, 2002, p. 87, 228). European powers faced two different, but converging, factors that eroded their capacities, and capabilities, to implement the full subjugation of the communities. First, the strengthening of nationalist and local communities' claim for independence, from the macro-evidence of the Turkish war of liberation against Europeans and later establishment of the Republic of Turkey in 1923, to the never-ending protests, revolts and insurgencies in Arab lands during the 1920s and 1930s (Gelvin, 2016, p. 189; Chalcraft, 2016, p. 198). Second, the open opposition and reluctant support for such European encroachment in the Mediterranean by two rising forces on the international stage, namely the Soviet Union and the United States of America. A major feature stood out in this process of reconfiguration of the politics of the 
Mediterranean space: the adoption by independence movements across the Arab and Turkish worlds of concepts and institutions, like the "nation", the "nation-state" and "modernity" born out of the recent history of continental Europe in order to assert the legitimacy of their projects and their integration in the international community on an equal footing (Hilane, 1969, p. 98). Both business elites moved north and south while plebeian groups migrated from Europe to Algeria, Tunisia, Egypt and later Libya (Petricioli, 2007,; Owen, 1989, p. 32). Political ideas like liberalism, constitutionalism and nationalism were "translated" by Ottoman, Turkish and Arab movements all advocating their own pattern of reform (Tibi, 1987, p. 95-122; Schumann, 2010, p. 13, 113; Abdel-Malek, 1970, p. 12, 28).

\section{The Option of a Postcolonial, Sovereign Mediterranean: I950s-1970s}

World War Two once again accelerated those patterns of development that had characterized the past decades, namely the demise of the European empires, decolonization and the bipolar competition of the Cold War. Despite their military victory against fascism in Italy and Nazism in Germany, both Great Britain and France had exhausted their finances in the war efforts and it did not take long for nationalist movements in the Arab world to shift their allegiance to the two rising superpowers, namely the United States of America and, to a lesser extent, the Soviet Union. The overall result was first the dismantling of the European institutional spheres of influence in the Arab Mediterranean. From the end to the Mandates in the Levant between 1946 and 1948, to the access to full independence of Libya in 1951, of Tunisia and Morocco in 1956 and finally of Algeria in 1962, all these newly established countries were recognized full sovereignty along the standards of the United Nations. However, most of the conservative or liberal nationalist forces which governed the states were far from advocating a clean break in relations with Europe: rising mostly from wealthy educated families engaged in trade and business with their northern partners they supported bilateral treaties of friendship which guaranteed the free flow of goods, capital and people across the Mediterranean (Hilane, 1969, p. 142; Corm, p. 243). On their part, European political forces devoted most of their attention to three main interrelated processes: first, the material and social reconstruction from the ruins of WWII; second, the system of Cold War alliances in setting domestic economic and institutional development; the integration process in Western Europe, which implied a major re-orientation of political and economic energies towards the continent.

The process of economic integration taking speed first in Western and later in Eastern Europe contributed to the marginalization of the Mediterranean basin as a prominent space for growth and development. Actually, the Trente Glorieuses of Western Europe centred first and foremost on the continental and transatlantic dimensions, with the south and east Mediterranean as a function of the latter: in particular, providing cheap labour and energy, or marginal consumption markets at best (Berend, 2006, p. 190). If the Cold War helped the demise of European imperialism in the Mediterranean by supporting nationalist movements through arms and diplomacy and unlocking colonial markets, it also introduced new lines of fracture between US and Soviet allies, which 
risked a new militarization of the Mediterranean space as well as the disruption of economic relations by way of sanctions and divergence in trade regimes. More often then not, the impact of the Cold War was the consolidation of territorial and political disputes among regional states (Pedaliu, 2016, 30; Trentin, Gerlini, 2012, p. 18). Eventually, despite attempts by France and Great Britain to retain their colonial empires, relations with former subjects shifted from exclusiveness to partnership (Elwood, 2012, 219; Bagnato, 2006, p. 180, 200). Except for Yugoslavia, lying on the shores of the Adriatic sea, Eastern European countries enforced their reconstruction on a national basis, and on the close relations with the Soviet Union, with programmes for regional integration playing a minor, if not marginal role (Berend, 2006, p. 150).

As a matter of fact, the first post-colonial phase of the late 1940s and early 1950s saw the convergence of Western European governments and the new Arab ruling elites on the basis of liberalism in economics and conservatism in society. However, those Arab elites which had previously banked on popular mobilization against European rule, found it increasingly difficult to match the claims and discourse for independence while retaining the patterns of social relations which had consolidated under European colonialism. Moreover, the experience of war efforts showed the pros of state intervention in planning the patterns of production, distribution and consumption (Vitalis, Heydemann, 2000, p. 100; Toninelli, 2002, p. 38). Alongside the Soviet Union and socialist forces, the United States also supported state intervention as a major engine for growth and "modernization", which found receptive ears among the ranks of the fast-growing state bureaucracy, civilian and military as well (Kingston, 1996, p. 12). The unwillingness or incapacity to match political sovereignty with social justice for the subaltern groups provided a major field of action for a new wave of nationalist forces in the Arab world that banked on the mobilization of both the salaried middle class and peasantry to challenge the "old" nationalists and grasp state power through an alliance with military officers. Despite their differences, the rise of Nasserism in Egypt from 1954-1956, Baathism in Syria from the mid-1950s and left-leaning brands of Arab nationalism in the Maghreb gave priority to inward-oriented development programmes that would satisfy popular demands for justice and upward mobility. The adoption of various patterns of import-substitution-industrialization (ISI), the nationalization of foreign trade and later on of natural resources like oil and gas were all intended to shift attention to the development of domestic production forces and consumption: external economic relations were to serve the needs of domestic development rather than the other way around, and the struggle to diversify foreign partnership beyond former imperial masters followed the same rationale (Richards, Waterbury, 201). Urban centres on the shore of the Mediterranean continued to attract considerable investments and retained their political relevance but development plans increasingly focused on the rural countryside of the interiors: agrarian reforms became the political hallmark of populist nationalism and, coupled with the expansion of public education and state employment, they provided effective opportunities for upward social mobility for traditionally marginalized communities.

On the whole, the consolidation of populist, modernizing nationalism in the Arab world and the process of European integration in the northwest of the continent put an end to the Mediterranean 
of the Levant. The irony was that the ensuing fragmentation occurred at the very moment when most of the Mediterranean countries endorsed similar patterns of development: the central state as the main engine for modern development of politics and society, and the mixed-economy, where state intervention in production was pervasive but not exclusive and, compared to the socialist states, fell short of effective planning in distribution and consumption (Bourgey, 1982, p. 23).

Against the background of the fragmentation of the Mediterranean space, new efforts were made to mend fences: in particular by those countries that had more stakes in the role of the Mediterranean as an open space for the exchange of goods, capital and people throughout the 1960s and 1970s (Trentin, 2012a, p. 287; Rey, Stiegler, 2017). Among these, some took the lead, like Nasser's Egypt and Tito's Yugoslavia in the early 1960s: the establishment of the Non Aligned Movement in Belgrade in 1961 exceeded the boundaries of the Mediterranean as it referred straight to the dynamics of the global Cold War. However, both Tito and Nasser shared the belief that both countries needed to set the Mediterranean free of the disrupting impact of the Cold War in order to continue trading and exchanging across the sea. After all, Yugoslavia was a socialist country which was one of the first recipients of US aid under the Marshall Plan of 1947, and later traded mostly with countries of the European Communities (EC): the Adriatic sea was a vital space for exchange (Kullaa, 2012). Egypt and other postcolonial Arab countries were in a similar situation: they could diverge in terms of international alliances and political orientation but were all closely bound to the Western and Eastern European markets in terms of production and consumption items. The principles of Neutrality, originally set by India's leader Jawarlal Nehru, were translated into "Positive/Active Neutrality" by Gamal Abd al-Nasser and finally established into the Non Aligned Movement: these were all meant to legitimize the possibility for postcolonial states to pursue their own patterns of political and economic development, as well as to diversify their international relations by way of establishing partnerships beyond strategic alliances with the Cold War superpowers, the European Communities, the CMEA or the Arab League; sovereignty here met diversification, which implied the existence of a viable space to practise them: here in the Mediterranean (Byrne, 2012, p. 14, 20).

The central state, or intergovernmental organizations, were appointed to act as the prime actors and ultimate guarantors of the "postcolonial" integration of the Mediterranean space. If during the Levantine period, multiple legitimate actors like nation-states, empires, religious communities and private business networks characterized this space, the central states now concentrated on the legitimacy to deal with foreign actors on the basis of exclusive representation of the new political unit of the "nation": international organizations and transnational networks, like the EC, the Arab League or Party and business organizations, might intervene only with the approval of the related states. On the one hand, as for legal and political affairs, the state centralized and monopolized jurisdiction over its citizens and all people residing and passing through its territory. The previous system of confessional or foreign tutelage over certain Ottoman subjects was dismantled according to the principle of exclusive sovereignty of the single state over territory and population (Gozzi, 2015, p. 160). Though conferences and meetings among different political 
parties continued to take place, the consolidation of one-party or hegemonic-party systems across the Arab countries conflated political representation and exchange to ruling forces. On the other hand, as for economic affairs, public and state enterprises covered a large share of economic activities in all the Mediterranean countries, which partially eased the difficulties connected to the synchronization between private and public business on planning, supply and payments. The state largely financed trade exchange and major deals in the form of granting loans to foreign consumers, providing state-guarantees to the domestic exporter or arranging clearing agreements. The energy commodities, like oil and later gas, were considered so strategic by producing and consuming countries around the Mediterranean that central states either established national companies or nationalized the private ones operating in their territories from the 1960s to the early 1970s: though public, semi-public or private, all companies were closely connected to governmental policies and could operate only along the lines of the latter (Trentin, 2012b, p. 292; Owen, Pamuk, 1998, p. 93). Despite all its limits and disrupters in the Mediterranean space, the 1960s recorded a remarkable convergence of income-distribution among countries in the north, south and east of the Mediterranean: the Gini Index of Bi-polarization stood at 0.06 compared to the later increase to 0.9 during the 1980s (Esteban, 2002, p. 18).

The energy shocks of the 1970s marked a transitional phase from the state-centric system of relations in the Mediterranean to the following European-led selective integration. In fact, the massive transfer of financial wealth from energy-consumers to energy-producing countries (oil and natural gas) provided selected Arab states in the Mediterranean with huge resources to invest domestically and internationally. At home, they basically led to the expansion of the public sector in production but foremost in social services and administration. At the Arab level, oil-rich states invested and provided loans to their "have-not" neighbours, which in turn had to open up their markets to foreign investors but at the same time continued to fund the deficit of their public sectors along the populist social contract or out of fear for popular unrest. If new spaces and opportunities were offered to private activities in economics as well as foreign investors, the state maintained its supremacy as domestic employer and economic partner (Richards, Waterbury, 1998, p. 201). Out of necessity, the energy-consuming Western European countries began to act collectively vis-à-vis their southern partners from 1972, when the European Communities launched the Global Mediterranean Policy (GMP) and the Euro-Arab Dialogue from 1974 (Calandri, 2009, p. 104). By the first initiative, the EC recognised that laissez-faire and free-trade had to be complemented by robust state-to-state partnership for economic development in the Mediterranean south, so that the Cooperation Agreements signed by the EC and single Arab states and Israel from 1976 to 1978 actually institutionalized public intervention as the main driver for inter-Mediterranean development and political stability; they also provided the institutional basis for the "shallow integration" for the decades to come (Trentin, 2012b, p. 225; Ayadi, Sessa, 2017, p. 16) $)^{2}$. Moreover, the first signs of the crisis of the Fordist, Keynesian pattern of development

2 Officially charged with more political content, the Euro-Arab Dialogue bore less fruit as soon as Arab states' solidarity in the Arab-Israeli conflict was disrupted by Egypt's signing of the Peace Treaty with Israel in 1979 and the EC made it clear that they could only support the recognition of the Palestinian national rights to their own state (Labate, 2016, p. 186); "Shallow integration refers to the simple liberalisation of trade through the dismantling of 
among EC core members was met with the first round of containment of migration flows from the Arab countries and Turkey (Paoli, 2015, p. 127).

\section{The EU-Led Neo-Liberal Integration of the Mediterranean}

The "Embedded Liberalism" of the 1970s unravelled by the mid of the 1980s when the decline of energy prices brought the redistribution system of oil rents within and among countries in the south and east of the Mediterranean to an abrupt halt. No longer able to fund their current account deficits by external borrowing, Morocco, Tunisia, Egypt, Turkey and later Algeria all had to ask for debt rescheduling and accept the financial austerity prescribed by foreign creditors and the related International Economic Organizations (IEO), like the International Monetary Fund and the World Bank (Harrigan, al Said, 2009, p. 10). As for the EC, the shift to so-called neoliberal doctrines for development came as early as 1985 with the Commission headed by Jacques Delors which stated that the EC would work with the IEO, and southern partners should align to the "discipline of competition": aid and investments would come with market liberalization and privatizations, and the EC would foster its own private companies to enter those markets in order to face off US and Asian competitors (Trentin, 2015, p. 101). Arab states began a slow but steady process of adjustment to the new rules of neoliberalism ${ }^{3}$ : the public sector was contained and later downgraded in terms of efficacy in production as well as delivery of services by curtailing funds, while private enterprise was prized as long as it was allied with political leadership; public monopolies were transformed into private ones, which struck major alliances with those foreign companies that were eager to enter the enlarging markets of the Arab countries and Turkey (Guazzone, Pioppi, 2009, p. 5-7; Hinnebusch, 2003, p. 204). Slowly but steadily the social constituencies of the Arab regimes began to move from popular, "plebeian" groups and classes towards wealthy, upper-class groups whose economic stakes and social status were strongly tied to their access to political ruling elites as well as international markets. Countries aligned with the European Communities and the United States moved first along this path: Egypt began implementing real structural reforms since the mid-1990s after the rents originated by the US-sponsored peace agreement with Israel in 1979, the re-establishment of good relations with Gulf Monarchies from 1984 and the rewards for participating to the II Gulf War in 1991 were not enough to fund public deficits and external debt. Tunisia and Morocco could not bank on the Egyptian "geopolitical" rents but could rely the political stability of the

tariffs between partner countries. Deep integration refers to the convergence of market conditions between partner countries, pursued through the dismantling of non - tariff barriers to trade and the approximation of regulatory frameworks" (Ayadi, Sessa, 2017, p. 16).

3 As for a definition of "neoliberalism" I refer to David Harvey: "Neoliberalism is in the first instance a theory of political economic practices that proposes that human well-being can best be advanced by liberating individual entrepreneurial freedoms and skills within an institutional framework characterized by strong private property rights, free markets, and free trade. The role of the state is to create and preserve an institutional framework appropriate to such practices. [...] Furthermore, if markets do not exist (in areas such as land, water, education, health care, social security, or environmental pollution) then they must be created, by state action if necessary. But beyond these tasks the state should not venture (Harvey, 2005, 2). 
new leadership by Ben Ali in Tunis and the monarchy in Rabat in order to relaunch their deeper connections with the European Communities and attract industrial and agricultural investments in their territories (Owen, 2004, p. 113). Having contained political opposition by the military coup in 1980, Turkey's conservative leadership embarked on structural adjustments throughout the decade, whose premium for the private sector was fostered by the decision in Ankara to increase its presence in Central Asia after the collapse of the Soviet Union in 1991 and later on in Iran and Arab countries: private enterprises as well as the championing of a moderate, liberal Islam would become the hallmarks of Turkish projection beyond Anatolia, and beyond the close ties with the European Communities (Aydin, 2005, p. 43, 51; Pamuk, 2008, p. 266). Worth mentioning was the case of Algeria that tried and failed to shape a political answer to the economic crisis of the mid-1980s: the ruling elite first by mobilized enlarged participation to the forces of Political Islam in 1988 and then, once these threatened the armed forces, the latter resorted to coercion, engulfing Algeria in a bloody civil war from 1991. The experience of Algeria in the 1990s would prove incisive for Euro-Mediterranean relations insofar as it led European and Arab elites to converge on and reward accordingly the containment and rejection of Political Islam in the name of political "stability" in the area (Martinez, 2000, p. 220).

The combination of financial austerity, liberalization and privatizations, however, did not live up to the expectations of a major boost in economic exchange between the EC and its Mediterranean partners. As a matter of fact, the low rates of growth experienced by most of the countries concerned proved problematic: first, they limited the overall volume of foreign trade; second, partners in the South registered rising deficits in their current accounts, not compensated by proportionate financial inflows from the North, namely FDI, loans or grants; the exchange concentrated on sectors which would not create many employment opportunities for local labour while migrations to the $\mathrm{EC}$, with the related remittances, become the more and more selective due to crisis and legal restrictions in Europe (Trentin, 2015, p. 106; Ayubi, 1995, p. 5). Overall, the poor economic results of the early structural adjustment of the early 1990s led to a partial reassessment by the EC in the mid-1990s. The collapse of the socialist camp in Central and Eastern Europe shifted the primary focus of the EC towards the enlargement to the former socialist republics and the deepening of their institutional and economic integration with the founding of the European Union (EU) in Maastricht in 1992 and the Single Market in 1993. However, the contemporary crisis in the Mediterranean area obliged engagement towards the south by launching the EuroMediterranean Partnership, or "Barcelona Process" in 1995 (Calandri, 2009, p. 113-115). This would prove a compromise between previous initiatives: on the one hand, it continued unabated on the promotion of neoliberal reforms in the south and east of the Mediterranean as the only solution to the economic crisis and integration into "globalization"; on the other, it recognized the weakness of the private sector as a driver of growth and integration, and provided major aid and public guarantees for investments through the MEDA programmes for those partners that would sign the Association Agreements. Moreover, the centrality of the economic dossier was accompanied with initiatives on the "social" and "cultural" level in order to contain the negative 
repercussions of neoliberal adjustment and to promote the principles, institutions and practices of liberal democracy in the region.

If the United States set themselves as the major military and diplomatic power during the 1990s in the Balkans, the Middle East and North Africa, and consequently in the Mediterranean space, the EU was the major reference for trade, finance and patterns of economic and institutional development. The Mediterranean space was a terrain to prove the "civil", "soft" features of European power in globalization (Cavatorta, Vincent, 2010; Adler, Crawford, 2004). Except for Libya and Syria, all countries signed the Association Agreements with the EU, which were set to construct a free-trade area within the mid-2000s as well as lead to a major integration and convergence between the southern and northern shores of the Mediterranean as for wealth and institutions. In terms of power relations, the initiative fitted well into the category of a hegemonic effort by the EU to integrate the Mediterranean space by delivering its own patterns of liberal institutions and neoliberal economics as "suitable" for the region (Ayadi, Sessa, 2017, p. 18-19), and fostering the construction of a social constituency of wealthy, liberal-minded elites which would lead the process in their own countries, both out of conviction and material interests. State sovereignty was still the basis for Euro-Mediterranean relations as long as it was necessary for negotiating and signing the agreements that would grant the legal and institutional frameworks for specific partnerships. However, the central state was not considered the main driver or political guarantor of reciprocity in partnership and integration: quite the contrary, along with the neoliberal discourse, the state and the public represented obstacles to economic and social integration because they were the "bulk" of conservative officials, or defenders of the status quo (Hinnebusch, 2012, p. 21).

Through the granting of European funds first to economic initiatives and then to institutional and cultural projects, trade exchange was back on the rise from the late 1990s together with the exchange of people through programmes of education and academic partnerships. This new round of integration actually benefitted the elites of the Arab countries since middle-income people were de facto excluded from those international partnerships. Moreover, the economic results were far from obvious. In fact, the increase in exchange and investments continued to be a percentage of the overall increase in international trade of the EU with neighbouring countries in Eastern Europe as well as with other partners in East Asia or North and South America. At the same time, the initiative did not stop the process of divergence in income levels between the shores of the Mediterranean basin, not to mention the explosion of income disparities within single countries: bipolarization of income between the north and south of the Mediterranean increased to 0.12 and 0.13 in 1990 and 1998 respectively, and the Gini Index set high at 0.34 for Arab countries (Esteban, 2002, p. 5, 20; Aita, 2011, p. 177, 205). Finally, the slow path in adoption of institutional reforms by Arab partners in terms of trade liberalization and standards of conduct proved to be a constant source of dismay and contempt among EU officials, which hoped to move from "shallow" to "deep" integration. The limited results in economic performance and integration along EU standards provided the background for those forces arguing for a stauncher approach towards the Arab partners in terms of conditionality. The attacks led by radical jihadi 
groups against the US in 9/11, 2001, Madrid in 2003 and London in 2005 added to the arguments for reassessing relations with the Arab countries and shifting priority to security and military partnership (Hollis, 2013, p. 352; Ben Achour, 2012, p. 33).

The poor results scored by the new round of European-led integration of the Mediterranean space led to different reappraisals of the European initiatives. First, in 2003 Brussels launched the Neighbourhood European Policy that focused on bilateral relations between the EU and single partners, hardened conditionality on economic cooperation, and excluded any future possibility of access to the EU. While the EU was strengthening its hand in the Mediterranean, Arab partners and Turkey began to assert their own claims for reciprocity in relations by diversifying their partnership towards other countries that were entering the Mediterranean markets: in particular, East Asian economies, like China, Korea and Malaysia increased their trade exchange and investment in the region, and supplied both low and medium-level technology products. A special role was played by Gulf countries whose surplus in hard currencies, earned by high energy prices, allowed them to invest massively in the Arab and Turkish markets, in particular in real estate, luxury tourism, transport facilities, information technologies, finance and banking. Though remaining the first economic partner for Maghreb countries and Turkey, the EU faced more competition than ever (Anima-Investmed, 2010). In sharp contrast with the previous energy shocks of the "long Seventies" (1969-1986), the more recent third "shock" (2001-2014) led to a process of both diversification of international economic relations of the Middle East and North Africa and a slight increase in economic integration among the GCC and Mashreq countries (World Bank, 2010). The ascendance of the East Asian economies provided an opportunity for Arab Mediterranean elites and Turkey to assert their autonomy against the European partners (Trentin, 2014, p. 75). A symbolic turn came with the political defeat suffered by Israel and its Western allies during the conflict in Lebanon in summer 2006 against Hizballah, and the US failure in turning Iraq into a stable and reliable ally, which was narrated as a momentous event for the forces of independence in the region. Against this trend, France advanced the proposal of the Union for the Mediterranean in 2007 that would re-assert the primacy of state institutions, intergovernmental dealings and multilateralism in the Mediterranean space in order to secure the legitimacy of ruling elites under mounting pressure from popular politics, the forces of Political Islam and international competition (Aliboni, 2008).

The unexpected eruption of popular uprisings across the Arab world as well as the social tensions fostered from Greece to Spain by the global economic crisis of 2008 exposed all the difficulties and limits of the patterns of development set out in the Mediterranean space in the last decades. Limited and unstable rates of growth, unprecedented concentration of wealth, dispossession and exclusion of middle and popular classes from wealth and power provided the context over which collective action took space and obliged the EU and ruling elites in the Arab world to reassess their policies again (Heydemann, 2013, p. 69). Though foreign relations were not high on the agenda of groups and movements of the Arab uprisings between 2011 and 2013, the return of popular and middle classes to the political stage had major consequences for international relations as well, and in particular for the Mediterranean space. In fact, the political support and economic 
collusion of European elites with former partners in Egypt and Tunisia led new actors in power to claim a major autonomy and reciprocity across the Mediterranean (McMurray, Ufheil-Somers, 2013). In both countries, the role of social, collective movements like trade unions and NGOs during the momentous events of the uprisings forced domestic elites and European partners to face the challenge of combining social and economic development. However, neither the EU nor the elites provided comprehensive solutions besides reasserting the validity of former patterns of development. This was adamantly clear in the EU policies after the 2011 Arab uprisings. After the initial stress on the support for "democracy" in March 2011, later documents confirmed the predominance of free-market economics and procedural democracy, to get back finally to the priority of "stabilization" against security threats: the EU looked for partners of whatever kind in the struggle against radical, jihadi movements and the containment of migratory flows (Teti, 2016, p. 1-4; Furia, 2012, p. 83). As such, the EU aligned with existing political regimes, from constitutional to absolutist monarchies, like Morocco, Jordan and the Gulf states, from constitutional to military-led republics, like Tunisia, Turkey, Egypt and Algeria. Programmes and funding for civil society and the promotion of democracy were curbed in line with desires by Arab governments and Turkey to reassert the primacy if not monopoly of the central state in the construction of foreign relations (Lynch, 2016, p. 75). Thus, within the Mediterranean space, the EU would support a system of international relations where the central state would uphold the role of institutional reference in security matters, while the "markets", namely private entrepreneurs, would act as the privileged actors for economic and social development (Teti, 2015, p. 22-23). As a matter of fact, strong neoliberal continuity characterized the EU response to the Arab uprisings and their subsequent development.

\section{Preliminary Conclusions: the Uneasy Combination of Sovereignty and Neoliberalism}

Currently, the Mediterranean space is experiencing a transformation phase where traditional powers are faltering while others are still entering the stage. The United States of America has lost the upper hand it enjoyed since WWII in diplomacy and military affairs after the failed campaigns in Iraq and Libya. The EU has retained most of its economic influence as a major trade and financial actor but suffers from a legitimacy crisis as a pole of attraction for stability and prosperity, both within and without its near borders. China and Russia have entered the stage, as military-diplomatic and economic partners respectively, but still as counter-partners to the main Western protagonists. Forces of Political Islam have made significant inroads in the Mediterranean, in Turkey, Morocco, Tunisia and Egypt but their record in government is still limited and highly disputed. As a consequence, competition has increased on the Mediterranean space among contending visions of partnership: one based on hegemonic integration, along the patterns set by the more powerful partner, namely the EU; another based on state sovereignty, where every single country retains its peculiar features in politics and economics, and negotiates the scope and depth of cooperation with those partners they praise for specific resources or assets. 
Despite their differences, Islamist and nationalist forces in the Arab countries of the Mediterranean and Turkey have recently moved towards re-asserting their sovereignty against so-called interference from external actors: from the EU to the US, Russia and China, depending on the issue at stake (Hinnebusch, 2012, p. 28). Europe remains divided on the issue: on the one hand, the European Union has continued with the imperial practice of convergence through assimilation of the subaltern partners to its own standards of conduct, delivered as the most effective recipe for development. On the other, populist right-wing movements across Europe claim a return to national sovereignty against elites and foreigners, which might converge with trends in the South of the Mediterranean if they were not framed in confrontational racist terms against Muslim people. In fact, essentialist narratives over the "other" identities are widespread in both Europe and the Arab and Turkish Mediterranean, fuelling exclusion and mutual animosity (Gozzi, 2012, p. 13).

Against the brief historical background set above, one might argue that in the previous two centuries the integration of the Mediterranean space was led by the European partners through liberalism and imperialism in the late XIX century, and neoliberalism and US brokerage in the late XX century: in both cases, the Arab and Turkish partners were placed on a subaltern status through the disruption of their political and social institutions. In this case the Levantine and neoliberal integration implied and sustained wide divergences in power and wealth distribution within subaltern countries and between these latter and Europe. In between, during the high times of nationalism and post colonialism in the mid XX century, the Mediterranean saw a convergence among partners for institutional and economic development (like, the central state and industrialization) and the parallel disintegration of the Mediterranean space into several, smaller political and economic units. During the 1970s, attempts were made to combine the reintegration of the Mediterranean as a common space of cooperation with respect for sovereignty and reciprocity, with notable results only as for commerce.

Today, like the late period of Levantine integration of the Mediterranean in the early XX century, we have witnessed the massive entry of social movements, north and south, that confront the imbalances of neoliberal integration and political subalternity. Yet, on the one hand they have not resulted in major changes in Euro-Mediterranean relations either because they have been repressed or because they focused collective action mainly on domestic issues. On the other hand, those forces in power that have supported "sovereignty" and questioned current EuroMediterranean relations have done so mainly along identity lines, either "European" or "Islamic" ones, which disrupt the commonalities that still feature the Mediterranean space. Last but not least, the question whether sovereignty in the XXI century would still be encapsulated into the centralized state as before, or whether it would assume new shapes that suit the multiple, shifting boundaries of the "people" in the Mediterranean space is still open to debate and political action. 


\section{References}

Abdel-Malek Anouar, eds. (1970). La pensée politique arabe contemporaine. Paris: Editions du Seuil.

Adler E., \& Crawford, B. (2004). Normative Power: The European Practice of Region Building and the Case of the Euro-Mediterranean Partnership (EMP). Berkeley CA: University of California.

Aliboni Roberto (2008). "Union for the Mediterranean: Building on the Barcelona Acquis", European Union Institute for Security Studies, 1.

Aita Samir (2011). Les travailleurs arabes hors-la-loi. Emploi et droit du travail dans les pays de la Méditerranée. Paris: L’Harmattan.

Anima-InvestMed (2010) Atlas des investissements et partenariats en Mediterranée, n.15.

Arrighi Giovanni, Iftikhar Ahmad, Miin-wen Shih (1999). "Western Hegemonies in World-Historical Perspectives", in Giovanni Arrighi, Beverly J. Silver, Chaos and Governance in Modern World System (pp. 217-269). Minneapolis:University of Minnesota Press,.

Ayadi, Rym Sessa, Emanuele (2017). Regional Integration in the Euro-Mediterranean. Key Dimensions, Status Quo and Prospects Towards Fundamental Rethinking, EMNES Working Paper, 1.

Aydin Zulkuf (2005). The Political Economy of Turkey, London, Pluto Press.

Ayubi Nazih, eds. (1995). Distant Neighbours. The Political Economy of Relations between Europe and the Middle East/north Africa. Reading: Ithaca Press.

Bagnato Bruna (2006). L'Europa e il mondo. Origini, sviluppo e crisi dell'imperialismo occidentale. Firenze: Le Monnier.

Ben Achour Yadh (2012). "Le dialogue avec l'Islam dans le cadre des relations euro-méditerranéenes" in Gustavo Gozzi eds. The Future of the Euro-Mediterranean Relationships (pp. 33-54). Bologna: il Mulino.

Bourgey André, eds. (1982). Industrialisation et changements sociaux dans l'Orient arabe. Beirut: Cermoc.

Braudel Fernand (1985). La Mediterranée. Paris: Flammarion.

Carpentier Jean, François Lebrun (2001). Histoire de la Méditerranée. Paris: Editions du Seuil.

Byrne Jeffrey J. (2012). "Algiers between Banding and Belgrade: Guerrilla Diplomacy and the Evolution of the Third World Movement, 1954-1962, in Massimiliano Trentin, Matteo Gerlini (eds.), The Cold War and the Middle East. Between Security and Development (pp. 11-28). Newcastle Upon Tyne: Cambridge Scholars Publishing.

Calandri Elena (2009). “L’eterna incompiuta: la politica mediterranea tra sviluppo e sicurezza”, in Elena Calandri (eds.), Il primato sfuggente. L'Europa e l'intervento per lo sviluppo (1957-2007) (pp. 89-117). Milano: Franco Angeli,.

Cavatorta, F., \& Vincent, D. (2010). The Foreign Policies of the European Union and the United States in North Africa: Diverging or Converging Dynamics. London: Routledge.

Chalcraft John (2016) Popular Politics in the Making of Modern Middle East. Cambridge UK: Cambridge University Press.

Corm George (2002). L’Europe et l'Orient. De la Balkanisation à la libanisation. Histoire d’une modernité inaccomplie. Paris: La Découverte.

Di Nolfo Ennio (2012) Introduction, in Ennio Di Nolfo, Matteo Gerlini, Il Mediterraneao attuale tra storia e politica (pp. 9-18). Venezia: Marsilio,

Ellwood David W. (2012). Una sfida per la modernità. Europa e America nel lungo Novecento. Milano: Carocci.

Esteban Joan (2002). "Economic Polarization in the Mediterranean Basin, Els Opuscles del CREI, 10 
Furia Annalisa (2012). "Between Securitization and Human Security: Security and Migration Issues i the Euro-Mediterranean Relations" in Gustavo Gozzi eds. The Future of the Euro-Mediterranean Relationships (pp. 83-98). Bologna: il Mulino.

Gelvin James (2016). The Modern Middle East. A History. Oxford, UK: Oxford University Press.

Gozzi Gustavo (2015). Umano, non umano. Intervento umanitario, colonialismo, "primavere arabe". Bologna: il Mulino.

Gozzi Gustavo (2012). "Prospects of Cooperation and Processes of Democratization in the Mediterranean", in Gustavo Gozzi eds. The Future of the Euro-Mediterranean Relationships (pp. 9-32). Bologna: il Mulino.

Guazzone, Laura, Pioppi Daniela (2009). The Arab State and neo-liberal Globalization: the restructuring of the state in the Middle East. Reading UK: Ithaca Press.

Harrigan, Jane, El-Said, Jane R. (2009). Aid and Power in the Arab World: World Bank and IMF Policy-Based Lending in the Middle East and North Africa. London: Basingstoke.

Harvey, David (2005). A Brief History of Neoliberalism. Oxford: Oxford University Press.

Heydemann Steven (2013). "Après le séisme. Gouvernement économique et politique de masse dans le monde arabe", in Eberhard Kienle, Laurence Louër, eds. "Economie politique des soulèvements arabes" (pp. 69-84). Critique Internationales, 61.

Hinnebusch Raymond (2003). The International Politics of the Middle East. Manchester, UK: Manchester University Press.

Hinnebusch Raymond (2012). "Europe and the Middle East. From Empire to Liberal Peace?" in Review of European Studies, 4(3), 18-31.

Hilane Rizkallah (1969). Culture et Développement en Syrie et dans les Pays retardées. Paris: Anthropos.

Hollis, Rosemary (2013). "Europe in the Middle East”, in Louise Fawcett eds., International Relations of the Middle East (pp. 344-362). Oxford: Oxford University Press,

Kingston Paul W.T, (1996). Britain and the Politics of Modernization in the Middle East, 1945-1958. Cambridge, UK: Cambridge University Press.

Kullaa Rinna (2012). Non-Alignment and Its Origins in Cold War Europe: Yugoslavia, Finland, and the Soviet Challenge. London: I.B. Tauris.

Labate Silvio (2016). Illusioni mediterranee. Il Dialogo Euro-arabo. Milano: Le Monnier.

Laurens Henry (2007). Orientales. Paris: CNRS Editions.

Laurens Henry (2010). Le rêve méditerranéen. Paris: CNRS Editions.

Lynch Marc (2016). The New Arab Wars. Uprisings and Anarchy in the Middle East. New York:, PublicAffairs.

Martinez Luis (2000). The Algerian Civil War, 1990-1998. New York: Columbia University Press.

McMurray David, Amanda Ufheil-Somers, eds. (2013) The Arab Revolts. Dispatches on Militant Democracy in the Middle East. Bloomington and Indianapolis: Indiana University Press.

Owen Roger (1981). The Near East in the World Economy 1800-1914. London: I.B. Tauris.

Owen Roger (1985). "The movement of labor in and out of the Middle East over the last two centuries: peasants, patterns and policies" in Georges Sabbagh, eds., The modern economic and social history of the Middle East in its world context (pp. 29-43). Cambridge, UK.: Cambridge University Press.

Owen Roger, Pamuk Şevket (1998). A History of the Middle East Economies in the Twentieth Century. London: I.B. Tauris.

Owen Roger (2004). State, Power and Politics in the Masking of Modern Middle East. London: Routledge, III ed. 
Paoli Simone (2015). “The Schengen Agreements and their Impact on Euro-MediterraneanRelations. The case of Italy and the Maghreb” in Journal of European Integration History, 21, 125-146.

Pamuk Şevket (1987). The Ottoman Empire and European Capitalism, 1820-1913: Trade, Investment and Production. Cambridge UK: Cambridge University Press.

Pamuk Şevket (2008). “Economic Change in the Twentieth Century: is the Glass More than Half Full?” in Resat Kasaba eds. The Cambridge History of Turkey, 3, (pp. 266-300).

Pamuk Şevket, Jeffrey J. Williamson (2009). Ottoman De-Industrialization 1800-1913: Assessing the Shock, Its Impact and the Response, Draft, JEL No. F1, N7, O2.

Pedaliu Effie G.H., (2012). "Fault Lines in the Post-War Mediterranean and the Birth of Southern Europe", 1945-1979: an Overview" in Elena Calandri, Antonio Varsori, Daniele Caviglia eds. Détente in Cold War Europe: Politics and Diplomacy in the Mediterranean and the Middle East (pp. 15-32). London: I.B. Tauris.

Petricioli Marta (2007). Oltre il mito. L'Egitto degli italiani (1917-1947). Milano:Bruno Mondadori.

Puryear, V. J. (1969). International Economics and Diplomacy in the Near East. Stanford CA: Archon Books.

Quataert Donald (1994). “The Age of Reforms, 1812-1914," in Halil Inalc1k, Donald Quataert (eds.) An Economic and Social History of the Ottoman Empire, 1300-1914 (pp. 759-946). Cambridge: Cambridge University Press.

Quataert Donald, The Ottoman Empire, 1700-1922. Cambridge, UK: Cambridge University Press.

Rey Matthieu, Valérie Stiegler (2017). "Nords et Suds, vers une nouvelle régionalisation (1950-1970)" in Matthieu Rey, Hnery Laurens (eds.) Méditerranéens politiques. Paris: Presse Universitaire de France.

Richards Alan, Waterbury John (1998). A Political Economy of the Middle East. Boulder CO: Westview Press. Scumann Christoph eds. (2010). Nationalism and Liberal Thought in the Arab East. Ideology and Practice. London: Routledge.

Teti Andrea (2015) "Democracy Without Social Justice: Marginalization of Social and Economic Rights in EU Democracy Assistance Policy after the Arab Uprisings". Middle East Critique, 24(1), 9-25.

Teti Andrea (2016). The EU's policy response to the Uprisings, Global Affairs, 1(4).

Thobie Jacques (1985) Ali et les 40 voleurs. Impérialisme et Moyen-Orient de 1914 à nos jours. Paris: Editions Messidor.

Tibi Bassam (1987). Arab Nationalism. Between Islam and the Nation-State. London, UK: MacMillan.

Toninelli Pier Angelo (2002). "Il processo di industrializzazione: tipologie e modelli", "Progresso, sviluppo e ciclo nel pensiero economico contemporaneo: un'introduzione”, in Pier Angelo Toninelli (eds.), Lo sviluppo economico moderno. Dalla rivoluzione industriale alla crisi energetica. Padova: Marsilio.

Trentin, Massimiliano, Gerlini Matteo, (2012). (Eds.), The Cold War and the Middle East. Between Security and Development. Newcastle Upon Tyne: Cambridge Scholars Publishing.

Trentin, Massimiliano (2012a), "Le Distanze del Mediterraneo. Europa e mondo arabo tra sviluppo e nazionalismo", in Il Mediterraneo attuale tra storia e politica, in Ennio Di Nolfo, Matteo Gerlini eds. (pp. 283-304).Venezia: Marsilio,.

Trentin, Massimiliano (2012b), "The Distant Neighbours and the Cooperation Agreements between the EEC and the Mashreq, 1977” in Elena Calandri, Antonio Varsori, Daniele Caviglia eds. Détente in Cold War Europe: Politics and Diplomacy in the Mediterranean and the Middle East (pp. 221-232). London: I.B. Tauris.

Trentin Massimiliano (2014). "Boom e Crisi. Lo sviluppo economico dei Paesi MENA negli anni Duemila a confronto con i lunghi anni Settanta”, in Barbara Airò, Massimo Zaccaria eds. I confini della cittadinanza nel nuovo Medio Oriente (pp. 71-86). Roma: Viella. 
Vitalis Robert, Steven Heydemann (2000). "Explaining State-Market Relations in Post-War Middle East" in Steven Heydemann Steven, (eds.), War Institutions and Social Change. Berkley CA: University of California Press.

Wallerstein Immanuel, Hale Decdeli, Reşat Kasaba (1987). “The incorporation of the Ottoman Empire into the world-economy", Huri Islamoglu-Inan (eds.), The Ottoman Empire and the World-Economy (pp. 88-100). Cambridge UK: Cambridge University Press,

World Bank (2010). Economic Integration in the Maghreb; Economic Integration in the Mashreq, Economic Integration in the GCC, Washington DC. 